\title{
Emma Brockes ja Megan Rapinoe, Yksi elämä. Megan Rapinoen tarina
}

Suom. Tero Valkonen. Helsinki: WSOY, 2021, 260 s.

Talouslehti Forbes on listannut yhdeksi 2020-luvun jalkapallotrendiksi pelaajien poliittiset kannanotot (Kidd 3.1.2020). Vaikka pelaajat usein varovat esittämästä poliittisia mielipiteitä ja kantoja, yhdysvaltalainen jalkapalloilija Megan Rapinoe on tässä suhteessa virkistävä poikkeus. Rapinoesta tuli maailmankuulu Yhdysvaltojen voitettua jalkapallon MM-kisat kesällä 2019. Elämäkerrassaan Yksi elämä Rapinoe hyödyntää tätä momentumia laajentaakseen poliittisen toimintansa aluetta jalkapalloviheriön ulkopuolelle.

Yksi elämä on pikemminkin poliittinen puheenvuoro kuin perinteinen urheilijaelämäkerta. Jalkapallon arvoturnaukset rytmittävät kerrontaa, mutta teoksen keskiössä on yksityiskohtaisten pelianalyysien sijaan Rapinoen poliittinen toiminta. Teosta voikin lukea myös siitä näkökulmasta, että ammattijalkapalloilijan pelitaitoon kuuluu nykyään myös politiikan ja retoriikan tuntemus (Palonen 2021, 94). Rapinoe käsittelee kirjassaan muun muassa vähemmistöjen oikeuksia, rasismia ja tasa-arvokysymyksiä. Max Weberin poliitikkokonseptioita hyödyntäen Rapinoe voidaankin nähdä erän̈laisena "tilapäispoliitikkona" (Weber 2009, 79). Weberin mukaan olemme kaikki tilapäispoliitikkoja silloin, kun äänestämme vaaleissa tai otamme poliittisesti kantaa.

Rapinoe reflektoi kirjassa useassa kohdin millaisia valta-asetelmia hänen omaan positioonsa kytkeytyy. "Se, että minulle on suotu puheenvuoro, liittyy elämäni muihin puoliin, muiden muassa siihen miltä näytän, mitä edustan ja mitä mielleyhtymiä edustamaani lajiin liittyy", Rapinoe kirjoittaa kirjan esipuheessa (s. 13). Tätä asemaansa hän haluaa käyttää nostaakseen esiin vaiennettuja ja marginalisoituja ääniä, eli antaa "maalisyöttöihin" vertautuvia tilaisuuksia myös muille, kuten hän jalkapalloanalogiaa hyödyntäen kertoo (s. 15).

\section{POLIITTINEN HERÄÄMINEN}

Vaikka Yhdysvalloissa jalkapallo on eritoten naisten peli (ks. Markovits ja Rensmann 2010 179-184), ei urheilullisesti lahjakkaan Rapinoen lajivalinta ollut ilmeinen. Jalkapallosta pitävät yhdysvaltalaiset ovat usein yliopistokaupunkien liberaaleja, ja Rapinoe varttui konservatiivisessa perheessä Reddingin kaupungissa Pohjois-Kalifornian maaseudulla. Hän toteaakin jalkapallon olleen hänen vanhemmilleen urheilulajeista vierain (s. 39), mutta ei juurikaan pohdi lajivalintaan kytkeytyviä poliittisia ulottuvuuksia.

Rapinoe harrasti kaksoissisarensa Rachaelin kanssa monia urheilulajeja, mutta jalkapallon pariin hänet innoitti ennen kaikkea Brian-isoveljen kiinnostus peliin. Se, mikä juuri jalkapallossa viehätti Rapinoeta, jää kuitenkin kirjassa osin avoimeksi kysymykseksi. Jalkapalloviheriö vaikuttaa kuitenkin tarjoavan hänelle estradin luovalle itseilmaisulle, ja hän viittaa pelaamiseensa usein "performanssina" tai esiintymisenä, mikä käy tietenkin hyvin ilmi myös hänen tavaramerkkituuletuksestaan. Hän juhlii maalejaan seisomalla rehvakkaasti yleisön edessä kädet sivulle ojennettuina. 
Rapinoen poliittinen herääminen ajoittuu hänen yliopisto-opintojensa alkuun. Hän pääsi opiskelemaan ja pelaamaan jalkapalloa Portlandin yliopistoon stipendin turvin, ja kaupungin liberaali perustunnelma oli hänelle mieleen. Vielä vuoden 2004 vaaleissa Rapinoe kertoo äänestäneensä George W. Bushia, kunnes hän sosiologiaa ja politiikantutkimusta opiskeltuaan oivalsi, että hän ei "missään tapauksessa ollut republikaani" (s. 78). Joulukuussa 2019 demokraattien esivaalien alla Rapinoe asettui tukemaan puolueen presidenttiehdokkaaksi senaattori Elizabeth Warrenia.

Rapinoen poliittisen toiminnan lähtökohtana ovat olleet seksuaalivähemmistöjen oikeudet, mutta hän huomasi jo varhain erilaisten tasa-arvokamppailujen olevan toisiinsa limittyneitä: "[e]i ollut mitään mieltä ajaa vain yhtä asiaa ilman, että se olisi yhteydessä muihin" (s. 189). Hänen poliittinen agendansa onkin laajentunut vuosien varrella. Syksyllä 2016 Rapinoe polvistui Yhdysvaltain kansallislaulun aikana tukeakseen amerikkalaisen jalkapalloilijan Colin Kaepernickin aloittamaa protestia rasismia vastaan. Lisäksi Rapinoe on toistuvasti kritisoinut Donald Trumpin toimintaa presidenttinä.

\section{RAPINOEN (POLIITTINEN) PELITYYLI}

Rapinoe ei tulkitse politiikkaa "pelinä", eikä hän juurikaan puhu politiikasta jalkapallotermejä käyttäen. Hän ei myöskään pohdi yhteyksiä pelityylinsä ja poliittisen aktivisminsa välillä, vaikka ne ovatkin paikoin ilmeisiä. Hän kuvailee itseään pelaajaksi, jolla on "isojen otteluiden geeni" (s. 89), ja tässä mielessä on helppo ymmärtää, ettei Rapinoe pelkää ottaa kantaa politiikan kysymyksiin sekä haastaa politiikan ja jalkapallomaailman valtaapitäviä.

Rapinoeta kuvaillaan usein luovaksi jalkapalloilijaksi. Hänen pelityyliinsä kuuluu tietoinen riskinotto ja arvaamattomuus (s. 105). Myös hänen poliittiset kannanottonsa vaikuttavat välillä yhtä improvisoiduilta kuin hänen peliliikkeensä ja ne tuntuvat hämmentävän hänen vastustajansa paitsi jalkapalloviheriöllä myös politiikan kentillä. Vuoden 2019 MM-kisojen aikaan Rapinoe ilmaisi suorasukaisesti kieltäytyvänsä vierailusta Valkoisessa talossa kutsun käydessä, mikä provosoi presidentti Trumpin sarjaan hämmentäviä tviittejä, joissa hän moitti Rapinoeta epäisänmaallisuudesta ja tästä huolimatta kutsui joukkueen Valkoiseen taloon vierailulle (s. 229-230). Rapinoen hilpeä kuvaus tapahtuneesta osoittaa, että hän inspiroituu siitä, miten hänen poliittisiin aloitteisiinsa vastataan: "Minulla ei MM-kisoihin lähtiessäni ollut mitään poliittisia pyrkimyksiä, mutta kun Trump kerran niin tahtoi, olin valmis ottamaan politiikan mukaan" (s. 230).

Ehkä huomiota herättävin Yhdysvaltain maajoukkueen poliittinen siirto on ollut haastaa maan jalkapalloliitto oikeuteen sukupuolisyrjinnästä kesän 2019 MM-kisojen alla. Kiista liittyi jo useamman vuoden ajan kyteneeseen riitaan naisten ja miesten majoukkueille maksettavista palkkioista. Yhdysvaltain naisten maajoukkueen palkkiorahat olivat huomattavasti pienempiä kuin miesten huolimatta heidän paremmasta menestyksestään.

Kiinnostavaksi Rapinoen kertomuksen tapahtuneesta tekee hänen kuvauksensa joukkueen keinoista ja strategioista palkkavaatimusten perustelemiseksi ja tuen saamiseksi niille. Ensinnäkin pelaajat tulkitsivat vuoden 2015 maailmanmestaruuden avanneen poliittisen tilaisuuden vaatimusten esittämiselle. Toisekseen jalkapalloliiton spontaanin tuen puuttuessa he joutuivat pohtimaan ja muotoilemaan argumentteja, joilla legitimoida palkkavaatimuksiaan neuvotteluissa. Retorisesti 
kyvykkäät pelaajat Rapinoen johdolla asettuivat näiden vaatimusten äänitorviksi julkisuudessa. On mahdollista spekuloida, että Rapinoe on oppinut tällaista tilannetajua juuri jalkapalloviheriöillä, jossa hänen oli pienikokoisena pelaajana luotava pikemminkin juonikkuuteen kuin ruumiilliseen ylivoimaan perustuva pelitapa, kuten hän kirjassa kertoo (s. 48).

\section{HIERARKIOIDEN JA SÄÄNTÖJEN VASTUSTAMINEN}

Rapinoen toiminnassa näkyy pyrkimys - jos ei aivan demokratisoida - niin ainakin haastaa sisäisiä hierarkioita ja toimintatapoja niissä joukkueissa, joissa hän on pelannut. Ranskassa Olympique Lyonnaisissa pelatessaan hän kyseenalaisti päävalmentaja Patrice Lairin näkemyksiä esimerkiksi yllätyksellisillä peliliikkeillään niin, että hänet passitettiin pelaamaan yksi ottelu B-joukkueessa. Rapinoen mielikuvien Ranska merkitsi "sosialismia tai ainakin sosiaalidemokratiaa" (s. 149) ja Yhdysvaltoja liberaalimpaa ilmapiiriä, mikä ei kuitenkaan vastannut todellisuutta.

Hän myös kummastelee, ettei "sääntöjen rikkomista" pidetty Ranskassa arvossaan (s. 150), mikä on yksi mielenkiintoinen eurooppalaisten ja yhdysvaltalaisten pelityylien ja jalkapallokulttuurien eroon liittyvä huomio, joita kirjassa muuten on harmittavan vähän. Rapinoe esittää myös kiinnostavia, joskin osin pinnallisiksi jääviä oivalluksia eurooppalaisten ja yhdysvaltalaisten erilaisesta suhtautumisesta peliin. Jalkapallon eurooppalaiset juuret tulevat kuitenkin kirjassa ilmi: "Euroopassa yleisö todella tietää mistä on kyse" (s. 136), Rapinoe kirjoittaa ja pohtii, että eurooppalainen yleisö arvostaa pelkkien maalien sijasta myös kaunista peliä ja taidokkuutta.

Rapinoe on aktiivisesti pyrkinyt uudistamaan Yhdysvaltain maajoukkueen toimintatapoja, joita hän tulkitsee vallankäytön näkökulmasta. Esimerkkinä naisurheilijoihin kohdistuneesta "vähättelyn kulttuurista" Rapinoe mainitsee Lontoon olympialaisissa pelaajien vapaaseen liikkumiseen säädellyn tiukan kontrollin ja sen, että pelaajilla täytyi turnauksen ajan olla kämppäkaveri "joukkuehengen" nimissä (s. 138-139).

Tällaista pelaajien holhoamista vastusti aikanaan myös brasilialaisessa Corinthiasin joukkueessa pelannut Sócrates, jonka mukaan pelaajien vapauden rajoittaminen sulkemalla heidät hotelliin ennen tärkeitä otteluita loukkasi pelaajien ihmisarvoa (Bellos 2002, 301-302). Sócrates tunnetaan myös siitä, että hän perusti Brasilian sotilasdiktatuurin aikana pelaajayhdistyksen Democracia Corinthias, joka on luultavasti pisimmälle viety yritys demokratisoida jalkapallojoukkueen johtamis- ja toimintatapoja (ks. Knijnik 2014). Corinthiasin pelaajat halusivat saada sananvaltaa omiin asioihinsa liittyen ja järjestivät äänestyksiä merkittävistä joukkuetta koskevista päätöksistä.

Vaikka Rapinoe ei viittaakaan Corinthiasin tai Sócrateen esimerkkiin, hänen kertomuksistaan käy ilmi samansuuntainen pyrkimys saada pelaajien ääni kuuluviin etenkin Yhdysvaltain maajoukkuetta koskevissa kysymyksissä. Pelaajat olisivat muun muassa halunneet vaihtaa joukkueen päävalmentajan Jill Ellisin ennen kesän 2019 MM-kisoja, ja vaikka maan jalkapalloliitto seisoikin Ellisin takana, pelaajien yhdessä ilmaistu tyytymättömyys muutti joukkueen sisäisiä valta-asetelmia niin, että Rapinoen tulkinnan mukaan pelaajat tosiasiassa johtivat joukkuetta (s. 214-215). Rapinoe kertoo muutamasta tapauksesta, joissa hän kritisoi Ellisin peluutusvalintoja, mutta ei puhu siitä, pyrkivätkö ja onnistuivatko pelaajat vaikuttamaan myös joukkueen peliryhmitykseen tai -taktiikkaan. 


\section{LOPUKSI}

Rapinoe pohtii kiinnostavasti niitä dilemmoja, joita politikoiva urheilija joutuu toiminnassaan ottamaan huomioon. Jos polvistuu Yhdysvaltain kansallislaulun aikana, missä tilanteissa olisi perusteltua polvistua myös vastustajajoukkueen kansallislaulun aikana? Vuonna 2017 Yhdysvaltain jalkapalloliitto määräsi maajoukkueen pelaajat seisomaan kansallislaulun aikana, mihin Rapinoe suostui pitkin hampain, koska säännön uhmaaminen olisi saattanut viedä häneltä paitsi työpaikan myös foorumin aloitteilleen. Myöhemmin kielto peruttiin.

Rapinoen pettymykseksi jalkapallomaailman valovoimaisimmat tähdet, kuten Cristiano Ronaldo tai Lionel Messi, eivät ole näkyvästi ottaneet kantaa poliittisiin kysymyksiin. Silloinkin kun jalkapalloilijat ottavat kantaa poliittisiin kysymyksiin, he perustelevat toimintaansa mieluummin vedoten ihmisoikeuksiin kuin politiikkaan, kuten esimerkiksi Manchester Unitedin pelaaja Marcus Rashford, joka koskettavalla vetoomuksellaan onnistui viime vuonna kääntämään pääministeri Boris Johnsonin pään vähävaraisten perheiden lasten kouluruokailua koskevassa kysymyksessä. Vähemmän tunnettu, mutta mielenkiintoinen esimerkki poliittisesti kantaaottavasta jalkapalloilijasta on Italian maajoukkueen ja Juventuksen kapteeni Sara Gama. Hän on rikkonut lasikattoja muun muassa nousemalla ensimmäisenä naisena Italian jalkapallon pelaajayhdistyksen varapuheenjohtajaksi. Gama mieltää poliittisen ulottuvuuden olevan läsnä kaikessa hänen toiminnassaan.

Kaikkiaan Yksi Elämä osoittaa, kuinka vaatimukset jalkapallon ja politiikan sekä laajemmin urheilun ja politiikan erottamisesta ovat käyneet kuluneeksi ja epäuskottavaksi fraseologiaksi. Teos havainnollistaa käsityksiä poliittisen toiminnan muodoista yli perinteisten osallistumistapojen, vaikka jalkapalloilijat eivät itse välttämättä tulkitse omaa toimintaansa yhtä selvästi poliittiseksi kuin Rapinoe. Samalla teosta voi tulkita kiinnostavana kuvauksena siitä, kuinka jalkapalloilijat voivat hyödyntää pelilukutaitoaan myös politiikan kentillä.

\section{LÄHTEET}

Bellos, Alex. 2002. Futebol: brasilialainen elämäntapa, suomentanut Jussi Eskola. Helsinki: Koala.

Kidd, Robert. 3.1.2020. 6 Trends That Will Shape Soccer In The 2020s. Forbes. https://www.forbes.com/ sites/robertkidd/2020/01/03/which-trends-will-shape-soccer-in-the-2020s/. Viitattu 15.4.2021.

Knijnik, Jorge. 2014. Playing for freedom: Sócrates, futebol-arte and democratic struggle in Brazil. Soccer \& Society 15:5, 635-654. https://doi.org/10.1080/14660970.2014.912014

Markovits, Andrei S. ja Rensmann, Lars. 2010. Gaming the World: How Sports are Reshaping Global Politics and Culture. Princeton: Princeton University Press.

Palonen, Kari. 2021. Jalkapallo, Eurooppa, parlamentarismi: Aspekteja Daniel Cohn-Benditin poliittisesta ajattelusta. Kosmopolis 51:1, 88-103.

Weber, Max. 2009. Politiikka ammattina ja kutsumuksena. Teoksessa Tiede ja Politiikka - kutsumus ja ammatti, suomentanut Tapani Hietaniemi ja Risto Hannula. Tampere: Vastapaino, 69-150. 


\section{KIRJOITTAJATIEDOT}

MIRA SÖDERMAN

YTM, väitöskirjatutkija (valtio-oppi)

Humanistis-yhteiskuntatieteellinen tiedekunta

Jyväskylän yliopisto

mikrsode@student.jyu.fi 